\title{
Application program to prepare child/family for venipuncture: experience report
}

\author{
Aplicativo para preparo da criança/família na punção venosa: relato de experiência
}

Aplicación para el preparo del niño/de la familia en la venopunción: relato de experiencia

\section{Mariana Lucas da Rocha Cunha', Simone Brandi', Graziela Fernanda Teodoro Bonfim', Karine Gottardo Severino', Gabriela Cintra de Freitas Almeida", Pedro Cunial Campos", André de Marco Toyama"}

\author{
' Faculdade Israelita de Ciências da Saúde Albert Einstein. São Paulo, Brazil. \\ "Instituição INSPER - Ensino e Pesquisa. São Paulo, Brazil.
}

\section{How to cite this article:}

Cunha MLR, Brandi S, Bonfim GFT, Severino KG, Almeida GCF, Campos PC, et al. Application program to prepare child/family for venipuncture: experience report. Rev Bras Enferm [Internet]. 2018;71(Suppl 3):1474-8.

[Thematic Issue: Health of woman and child] DOI: http://dx.doi.org/10.1590/0034-7167-2017-0386

\section{Submission: 06-06-2017 Approval: 7-31-2017}

\section{ABSTRACT}

Objective: To report the experience of development of an application program to prepare child and family for venipuncture. Method: Experience report on an application program developed in the professional nursing master's degree program in partnership with engineering undergraduate students. Results: The application program allows the child to understand the venipuncture procedure in a ludic and interactive manner. Its development occurred in three stages: identification of client's needs, definition of components, and prototype elaboration. Final considerations: The application program, besides being directed to care and education of children and families, is able to meet the nurses' needs to prepare them for venipuncture. Moreover, it is worth mentioning the importance of multidisciplinary approach for the concretion of similar projects.

Descriptors: Pediatric Nursing; Education in Nursing; Games and Toys; Hospitalized Child; Technology.

\section{RESUMO}

Objetivo: relatar a experiência de desenvolvimento do aplicativo para preparo da criança e família na punção venosa. Método: relato de experiência sobre um aplicativo desenvolvido no Mestrado Profissional em Enfermagem em parceria com um curso de Engenharia Resultados: o desenvolvimento do aplicativo aconteceu em três etapas, a saber identificação das necessidades do cliente; definição dos componentes e a elaboração do protótipo. O aplicativo permite à criança compreender o procedimento de punção venosa de forma lúdica e interacional. Considerações finais: acredita-se que o aplicativo possa atender às necessidades dos enfermeiros no preparo da criança e família no procedimento de punção venosa. Destaca-se, ainda, a importância da multidisciplinariedade para a concretização de projetos semelhantes a estes. O desenvolvimento do aplicativo foi realizado com sucesso por se tratar de uma tecnologia que se presta ao cuidado e a educação da criança e família.

Descritores: Enfermagem Pediátrica; Educação em Enfermagem; Jogos e Brinquedos; Criança Hospitalizada; Tecnologia.

\section{RESUMEN}

Objetivo: Relatar la experiencia de desarrollo de la aplicación para el preparo del niño y de la familia para la venopunción. Método: Relato de la experiencia sobre una aplicación desarrollada en la maestría profesional en enfermería en alianza con un curso de ingeniería. Resultados: La aplicación permite al niño comprender el procedimiento de la venopunción de manera lúdica e interactiva. Su desarrollo se dio en tres etapas: la identificación de las necesidades del cliente, la definición de los componentes y la elaboración del prototipo. Consideraciones finales: La aplicación puede atender a las necesidades de los enfermeros en el preparo del niño y de la familia para el procedimiento de la venopunción. Se destaca todavía la importancia de la multidisciplinariedad para la concretización de proyectos similares. La aplicación, que se presta al cuidado y a la educación del niño y de la familia, ha sido desarrollada con éxito. Descriptores: Enfermería Pediátrica; Educación en Enfermería; Juegos y Juguetes; Niño Hospitalizado; Tecnología. 


\section{INTRODUCTION}

Research has demonstrated that disease and hospitalization are significant events in any child's life, and that they may cause, among other several feelings and behavioral attitudes, pain, sadness, suffering, crying, aggressiveness, fear and anxiety - difficult situation experienced not only by the child but also by the family ${ }^{(1-2)}$.

The anxiety caused by hospitalization can be understood as

a multidimensional phenomenon, characterized by biological and psychological aspects caused by the stressful and threatening process of insertion into hospital environment. In this context, the child is apart from social and family interaction, starts living with strangers and, many times, is submitted to invasive and painful procedures, besides having his/her recreational activities partially interrupted ${ }^{(3)}$.

Among the procedures considered painful and invasive, venipuncture stands out, and it is one of the most used procedures in healthcare. It is estimated that, during hospitalization, $80 \%$ patients are submitted to intravenous therapy (IV), one of the most challenging procedures for the nursing professional within pediatrics context, precisely for causing terror and anxiety in both child and family(4).

\section{THEORETICAL FRAMEWORK}

The therapeutic toy (TT) technique is one of the strategies used by the nurse to minimize fear and anxiety in invasive and painful procedures, as venipuncture. The TT is a structured activity that allows the child to relief the anxiety generated by atypical and threatening experiences through toys as dolls, toy pots, hospital materials (syringe, needle, stethoscope), among others. The nurse is the professional qualified and licensed to use the $\mathrm{TT}^{(5)}$.

For the parents, the use of the TT to prepare the child for venipuncture promotes a quieter environment, besides distracting and favoring the acceptance of the procedure. The technique favors the control of the situation by the child, once he/she "shifts from passive to dominant role, takes control and has freedom to express him/herself" in critical events ${ }^{(5)}$. It is important to mention that the TT stimulates the child to collaborate with the procedure, since he/she presents feelings symbolically connected to anxiety due to lack of knowledge of the therapeutic process phases ${ }^{(6)}$, what reinforces the relevance of previously explaining what will be done ${ }^{(7)}$. Similarly, when realizing that the child is more relaxed about the preparation for the procedures, the parents become calmer, safer and more confident about the nursing team ${ }^{(5)}$.

Complementing the use of the TT, the 21st Century is marked by technologies that became the basis for many activities in peoples' lives, including in the maintenance of social relationships. Even before being literate, the child learns how to use most technological resources available in electronic devices. In this context, the traditional recreational activities, which involve playing with dolls, balls and toy pots, are increasingly rare $^{(8)}$. Then, how to continue to prepare the child through the therapeutic toy in an attractive way?

Currently, children have difficulties to express feelings and affliction in the real world ${ }^{(8)}$. Thus, in the technological era, health professionals need to seek alternatives to establish closer communication with the children so as to keep them interested in information that is complex and outside the usual pattern of normality.

Reflecting on this so important change in the paradigm of care and education in health, and with the purpose of helping the child to experience difficult events as disease and hospitalization, there was the idea of developing an application program that could be used in accordance with the principles of the TT. The application has the purpose of preparing the child for venipuncture, a threatening procedure in his/her vision. The use of the application aims at meeting the nurses' needs to prepare the child by playing and, at the same time, being in line with the child's current interests.

\section{METHOD}

This article reports the experience of development of an application program used to prepare child and family for venipuncture. The initial idea was conceived from the mandatory subject called "Education in health: child and family", part of a professional nursing master's degree program, as proposal of educative action that might result in a strategy of intervention by the nurse. The activity proposed in the subject aimed at the planning and description of an educative action, establishing the objectives (or results) intended and the definition of the target audience, besides material and human resources needed. Thus, the students defined a project directed to the elaboration of an educative strategy whose target audience was the hospitalized child and his/her family.

The first material elaborated was a leaflet with basic information on venipuncture, directed to children and families. However, it was noticed that, despite presenting proper language, with illustrative figures and important information, the material was likely not to cause the effect expected regarding interaction and attention of children and family, considering the present panorama that is experienced in the care of hospitalized children.

This germinal activity was important, once the choice of the theme reflected the experience of the nurses involved in the project. Nevertheless, the educative proposal still demanded improvement to be put in practice. Due to this concern, there appeared discussions on the development of an application program to prepare child and family for venipuncture.

The development of this application occurred from May 2016 to June 2016, as part of the activities of the subject named "Agile Collaborative Development", in a project of national interchange with Insper, another education institution of the municipality of São Paulo, with participation of undergraduate students and professors coming from the $3^{\text {rd }}$ semester of the Computer Engineering Course of the institution.

The partnership with Insper happened after the evaluation of the "ApplicaTIV" program by the Technological Innovation Center of Hospital Israelita Albert Einstein (TIC-HIAE) regarding the following proposal aspects: originality, strategic alignment with the Sociedade Beneficente Israelita Brasileira Albert Einstein, non-infringement of third parties' rights and cost/benefit ratio.

For being an experience report, this study was not submitted to the assessment of the Research Ethics Committee of the institution responsible for the project. 


\section{RESULTS}

The results will be presented according to the phases of development of the application program: identification of client's needs; definition of components; and prototype elaboration.

\section{Identification of client's needs}

The partnership between the two education institutions has started with meetings that gathered engineering undergraduate students, nursing master's degree students, the TIC team and the master's degree professor. The engineering students had to know the needs of the health professionals, here considered clients, so that the tool would meet their purposes properly. This phase was called "briefing on the application program".

The first meetings were based on the presentation of themes by the nursing master's degree students to the engineering students, so as they could understand the importance and complexity of venipuncture within pediatrics context. The following concepts were presented: meaning of hospitalization for the child; skills of communication with the child; therapeutic toy meaning; composition of venipuncture stages; professional responsibility, and nurse's approach to child and family for this procedure.

The central identification of functionalities required for the application was based on the following: what the health professionals expected from it and the definition of its purpose; the gap that would be filled by it regarding the assistance to the child; and its target audience. Engineering and nursing students also discussed in which technological devices it would be made available.

In order to facilitate the engineering students' understanding of venipuncture, images of the materials used in the procedure were provided, besides descriptions of venipuncture, and a video of preparation of the child through the $\mathrm{TT}$, made in realistic simulation molds. One of the nurses filmed the performance of venipuncture on a doll, orientating the engineering students on how the procedure occurs in practice, stage by stage, so that they could understand some of the steps that must be followed and respected.

\section{Definition of components of the application program}

It was defined that the application program should be interactive, that is, the child would be able to choose some details for his/her own character on a menu of "faces" with different characteristics (sex, skin color, hair color and accessories, as head scarves). This interaction would be available on the initial page, establishing the first contact between the child and the application.

For the application prototype, the engineering students sought to define the main values embedded in each application screen, defining stages for the development of the final product. In the process, the students based on an agile methodology for management and planning of software projects called Scrum.

Afterward, the development team met to divide the several stages of the process, each one with its respective value delivered to the client. The division of the process was presented in full, seeking to realize which part could be concluded in just one week, delivering the highest value possible. By the end of every week, what had been developed so far was presented to the nursing master's degree professor and students through video conference. Weekly feedback was also offered in order to perform possible changes and adjustments.

The tools used in the development of the application program were Android Studio ${ }^{\circledR}$ and Adobe Illustrator ${ }^{\circledR}$. Android ${ }^{\circledR}$ was chosen as mobile platform due to the large number of pieces of equipment that use it, low associated cost and development team's knowledge, which has already studied the platform in classroom. Adobe Illustrator ${ }^{\circledR}$ was chosen due to the familiarity of the team's graphic designer with this tool.

The final application program, developed in around two months, is composed of four interactive screens where the child can simulate the venipuncture procedure. Screen by screen, the user needs to make decisions to perform the procedure in the right sequence - as it occurs in venipuncture in practice -, but in a very ludic way.

The child chooses the doll which he/she identifies with, and it appears lying in the hospital bed. In front of it there is a tray with basic materials for venipuncture: cotton, tourniquet, needle, syringe and medication. A signal indicates to the child what he/she has to do: to "drag" from the tray the items to perform the venipuncture on the doll. First, the tourniquet, then the disinfection with cotton (some germs appear on the doll's arm, which disappear after the disinfection), and so on.

Figures 1 and 2 exemplify some screens of the application. In Figure 1, there are the doll in bed and the indication of the site where venipuncture will be performed. In Figure 2, the arm to be punctured is closer, and the red color indicates that this is the moment to remove the tourniquet, because, according to the procedure, the child was able to puncture the vein.

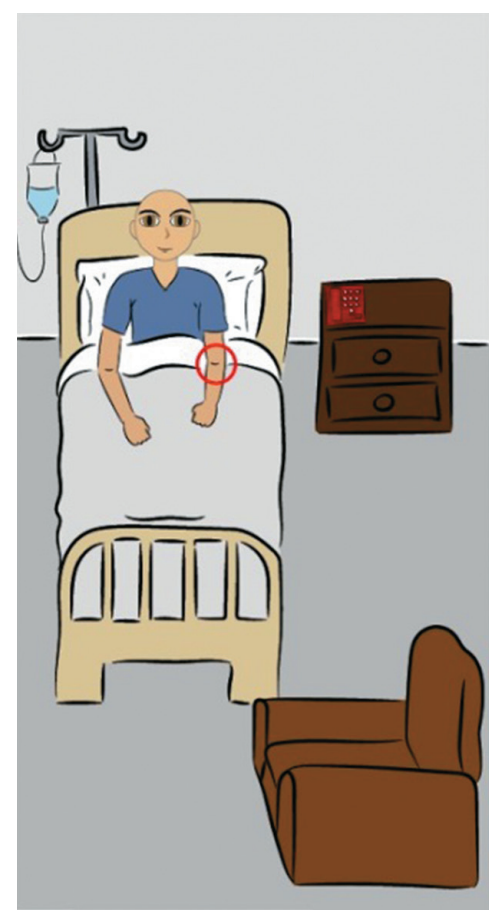

Figure 1 - Child in bed

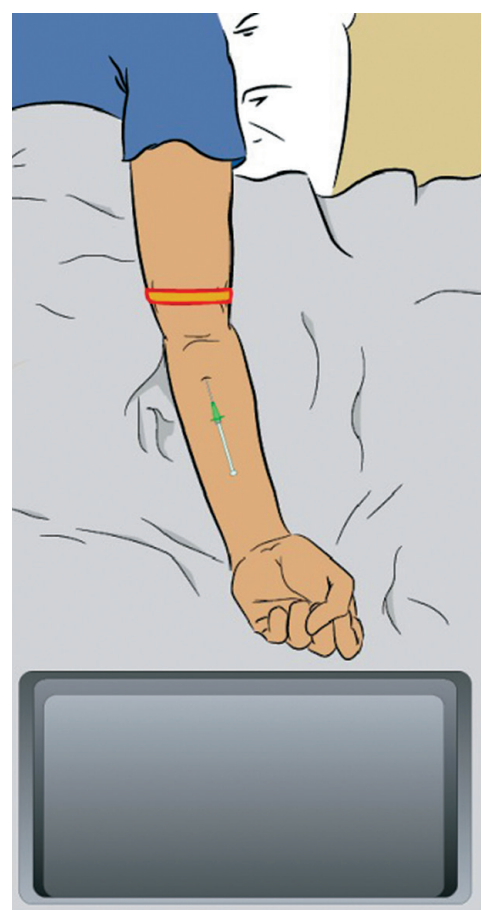

Figure 2 - Venipuncture site 
The child can play as many times as he/she wants, alone, together with the professional, family or other children in the same situation. The application program - which can be used before or after venipuncture, aiming at relieving tensions according to what is recommended by the TT - was called AplicaTIV.

\section{DISCUSSION}

Proposing strategies that minimize the child suffering in painful and threatening procedures is part of nurse's role, and, in a ludic way, the therapeutic toy allows the child to better understand the procedures to which he/she will be submitted during hospitalization ${ }^{(5)}$. In this sense, the development of the application program meets the child's play expectations, currently more turned to technology. This type of care, which may contribute to a "nursing care model Care with Play", is configured as understanding and focused on the need of both child and family.

Tools, processes or materials created from the technical and scientific knowledge may be called technology. In the context of care, nursing uses technology to offer safety, practicality and attention to the patient ${ }^{(9)}$. The technology developed in this research is intended to child and family both education and care, once it values the need to inform these individuals and assure their safety.

If, on the one hand, there are discussions on the advantages of using technology in the social development of children ${ }^{(8)}$, this reality has been expanded and accepted as beneficial under health perspective. The proposal to develop an application program to prepare the child is aligned with the tendency appointed by a study of revision on the use of technology in pediatric care, which demonstrated that application programs have been increasingly used in healthcare. Chronic diseases and their relation with the handling of pain by the child have been leading the motivations to research, and application programs are important tools to expand engagement, self-care and adherence to treatments ${ }^{(10)}$.

\section{Study limitations}

Once it is an experience report on the development of the application program, it was not possible to evaluate its usefulness and consequent acceptance by children and families. These will be the next stages with the research progress.

\section{Contributions to the nursing field}

Preparation for venipuncture by means of an application program, aiming at education and care, is a strategy that strengthens the nurse's performance regarding children and families, besides stimulating the progress of nurse's role to beyond assistance, since it allows the creative practice with development of technology for care.

\section{FINAL CONSIDERATIONS}

The application program developed is considered able to meet the nurses' needs to prepare child and family for venipuncture. Using the potential of innovation offered by health area and due to his/her close contact with children and families, the nurse must adopt a professional attitude of availability to find solutions that facilitate child care.

In this sense, new tools as the AplicaTIV can help the interactions with these patients, reducing stress caused by experiences that are significant to the child, and stimulating nurse's awareness of the need to provide integral care to the child in a less technical and more humanized manner.

For joining two extremely different areas of practice, nursing and engineering, the project reaffirmed the importance of working in multidisciplinary teams to solve problems in healthcare. The union of distinct and specialized knowledge for a common cause has successfully achieved the initial goal of the project: the development of a technology that is for care and education of the patient and his/her family.

The development of the application contemplated the first phase of this project, whose next steps are to evaluate the usefulness of the product, validation of the content by specialists and target audience, and the consequent verification of the application by professionals specialized in health and information technology areas.

\section{ACKNOWLEDGEMENT}

We would like to thank Denise R. Lobato, coordinator of the Innovation Center of HIAE, for allowing a partnership between both courses and the viability of this project. We are also grateful to professor Marcelo Hashimoto, responsible for the Agile Collaborative Development Projects subject, and to the engineering students of Insper/SP, for the incentive and orientation.

\section{REFERENCES}

1. Santos PM, Silva LF, Depianti JR, Cursino EG, Ribeiro CA. Nursing care through the perception of hospitalized children. Rev Bras Enferm [Internet]. 2016[cited 2017 Mar 10];69(4):646-53. Available from: http://dx.doi.org/10.1590/0034-7167.2016690405i

2. Luz JH, Martini JG. Understanding the meaning of being hospitalized in daily lives of children and teenager with chronic diseases. Rev Bras Enferm [Internet]. 2012[cited 2017 Mar 10];65(6):916-21. Available from: http://dx.doi.org/10.1590/S0034-71672012000600005

3. Gomes GL, Fernandes MGM, Nóbrega MM. Hospitalization anxiety in children: conceptual analysis. Rev Bras Enferm [Internet]. 2016[cited 2017 Mar 10];69(5):884-9. Available from: http://dx.doi.org/10.1590/0034-7167-2015-0116

4. American Academy of Pediatrics Section on Hospital Medicine. Caring for the hospitalized child: a handbook of inpatient pediatric. Section on hospital. Intravenous Lines. ISBN-13: 978-1-61002-115-9 2013. p. 153-60. 
5. Rocha PK, Caleffi CC, Anders JC, Souza AI, Burciaga VB, Serapião LS. Contribution of structured therapeutic play in a nursing care model for hospitalized children. Rev Gaúcha Enferm [Internet]. 2016 [cited 2017 Mar 10];37(2):e58131. Available from: http:// www.scielo.br/pdf/rgenf/v37n2/en_0102-6933-rgenf-1983-144720160258131.pdf

6. Fonseca MR, Campos CJ, Ribeiro CA, Toledo VP, Melo LL. Revealing the world of oncological treatment through dramatic therapeutic play. Texto Contexto Enferm [Internet]. 2015 [cited 2017 Mar 10];24(4):1112-20. Available from: www.scielo.br/pdf/ tce/v24n4/pt_0104-0707-tce-24-04-01112.pdf

7. Pontes JE, Tabet E, Folkmann MAS, Cunha MLR, Almeida FA. Therapeutic play: preparing the child for the vaccine. Einstein[Internet]. 2015[cited 2017 Mar 10];13(2):238-42. Available from: http://dx.doi.org/10.1590/S1679-45082015AO2967

8. Paiva NM, Costa JS. A influência da tecnologia na infância: desenvolvimento ou ameaça. Psicol PT [Internet]. 2015[cited 2016 Dec 29]. Available from: www.psicologia.pt/artigos/textos/A0839.pdf

9. Costa NP, Polaro SH, Vahl EA, Gonçalves LH. Storytelling: a care technology in continuing education for active ageing. Rev Bras Enferm [Internet]. 2016 [cited 2017 Mar 10];69(6):1132-9. Available from: http://dx.doi.org/10.1590/0034-7167-2016-0390

10. Smith K, Iversen C. Apple apps for the management of pediatric pain and pain-related stress. Clin Pract Pediatr Psychol[Internet]. 2015 [cited 2017 Mar 10];3(2):93-107. Available from: https://www.apa.org/pubs/journals/features/cpp-0000092.pdf 